\title{
Tritium concentration analysis of groundwater samples from the environmental monitoring program at IPEN, São Paulo, Brazil
}

\author{
L. Leonardo and B.R.S. Pecequilo \\ Environmental Radiometric Division, Instituto de Pesquisas Energéticas e Nucleares, \\ Av. Prof. Lineu Prestes, 2242 Cidade Universitária, 05508-000 São Paulo, SP, Brazil \\ e-mail: brigitte@ipen.br
}

\begin{abstract}
Tritium concentrations of groundwater samples from the Environmental Monitoring Program at IPEN (Institute of Nuclear and Energetic Researches), São Paulo, Brazil, covering the years 2000 to 2003, were determined by liquid scintillation counting and the results laid in the range of $20 \mathrm{~Bq} \cdot \mathrm{L}^{-1}$ to $91 \mathrm{~Bq} \cdot \mathrm{L}^{-1}$. The effective committed dose for general public considering the highest concentration value is $1.3 \mu \mathrm{Sv}^{\circ} \cdot \mathrm{y}^{-1}$, which is below the ICRP dose limit of $1 \mathrm{mSv} \cdot \mathrm{y}^{-1}$. Tritium concentration of radioactive liquid effluents samples from the IEA-R1 research reactor storage tank showed values from $3.6 \times 10^{3} \mathrm{~Bq} \cdot \mathrm{L}^{-1}$ to $6.2 \times 10^{3} \mathrm{~Bq} \cdot \mathrm{L}^{-1}$, approximately 1000 times below the Brazilian daily discharge limit of $3.7 \times 10^{6} \mathrm{~Bq} \cdot \mathrm{L}^{-1}$.
\end{abstract}

\section{INTRODUCTION}

In a nuclear or radiactive facility we must always ensure that, under normal operating conditions, any waste discharged from it will not give rise to radiation exposures of members of the public above the limits stipulated by competent authorities [1]. Situated in the São Paulo University campus, on the northwest of the city of São Paulo, Brazil, the Institute of Nuclear and Energetic Researches (IPEN) covers an area of 500,000 $\mathrm{m}^{2}$ and has a major role in several fields of the nuclear activity. The major nuclear and radiactive facilities at IPEN, that contribute to the term source are the IEA-R1 Swimming Pool Nuclear Research Reactor, two isochronal Cyclotrons, a Nuclear Fuel Center and a Radiopharmacy Center. The normal operation of these facilities release to the environment radioactive liquid or gaseous effluents. The liquid effluents are stored in retention tanks and after radiological assessment, released to the sewer system of IPEN. These discharges go to Pinheiros River and follow to Billings reservoir. The water from Pinheiros River is not used for consummation or food cultivation [2]. As complete removal of radioactivity from gaseous and liquid effluents discharged to the environment is practically impossible to achieve, all released effluents will always contain small amounts of radioactive waste material. In order to estimate the radiological impact to the environment around IPEN facilities, an environmental monitoring program was established [3], assuring that the levels of discharge stay as low as reasonably possible.

Within this program, samples of groundwater, rainwater and filters for air sampling in the influence area of IPEN facilities are measured by using gamma spectrometry, total alpha and beta counting and instrumental neutron activation analysis [4], [5]. The external exposure is determined by thermoluminescence dosimeters [6]. Groundwater samples are collected bimonthly from six wells and rainwater samples are collected monthly at four points. One of the most important radionuclides that 
can be produced in a nuclear reactor like the IEA-R1 reactor is tritium [7], produced by ternary fission and neutron activation in reactor elements. Tritium, the only radioactive isotope of hydrogen, with half-life 12.35 years, is a pure beta particle emissor, with maximum energy of $18.6 \mathrm{keV}$. Its range in air is approximately $5 \mathrm{~mm}$ and in aluminum $2 \mu \mathrm{m}$, which difficult the detection in window detectors with typical thickness from 6 to $9 \mu \mathrm{m}$. Among several existing methods for tritium determination, liquid scintillation counting presents good results for analysis considering the discharge limits and time for samples preparations [8].

In this work, the tritium concentration was determined by liquid scintillation in samples from IPEN reactor retention tanks and in groundwater samples from the environmental monitoring program.

\section{MATERIALS AND METHODS}

\subsection{Tritium specific activity}

For tritium, a pure beta emitter with a maximum energy of $18.6 \mathrm{keV}$, we established the following procedure for water samples: the sample is slowly distilled for removing non-volatile radionuclides and usual quenching materials near dryness, assuring complete transfer of tritiated water. The first $5 \mathrm{~mL}$ are discarded to avoid eventual system contamination. A distilled volume mixed with liquid scintillation Instal-Gel XF of Packard in the proportion 1:15, is manually shaken and after, refrigerated and reserved in darkness for 6 hours. The samples were counted by 100 minutes on a Packard TRI-CARB 2100TR liquid scintillator spectrometer. The spectra were analyzed with the Packard SPECTRAGRAPH software.

The calibration quenching curve was built using several Packard H-3 standards of same activity, but with different quenching factors. The curve represents the quenching parameters (QIP) values obtained by external induction of Barium-133 Compton spectrum in the samples (transformed Spectral Index of the External standard -tSIE-), as a function of the counting efficiency. The tSIE values are relative, 0 for larger quenching level and 1000 for sample without quenching. Figure 1 shows the calibration quenching curve logarithmically fitted.

The tritium specific activity in $\mathrm{Bq} \cdot \mathrm{L}^{-1}$ was calculated as in equation 1 , considering also the background radiation, determined for every sample run.

$$
A=\frac{C P M}{E_{S} \times 60}-\frac{B g}{E_{B g} \times 60}
$$

Where:

$A \quad=$ specific activity of the sample $\left(\mathrm{Bq} \cdot \mathrm{L}^{-1}\right)$

$\boldsymbol{C P M}=$ counts per minute - sample

$\boldsymbol{B g}=$ counts per minute - background radiation

$\boldsymbol{E}_{\boldsymbol{s}} \quad$ = sample counting efficiency

$\boldsymbol{E}_{B g} \quad=$ background radiation counting efficiency 


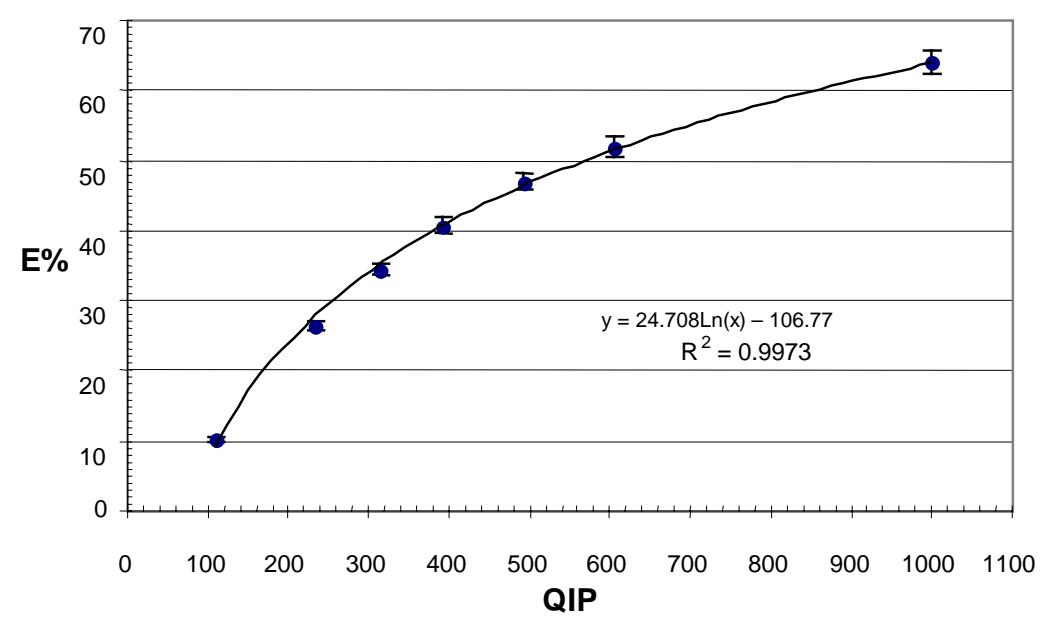

Figure 1. Experimental calibration quenching curve of the Packard Tri-Carb 2100 TR scintillator spectrometer determined from the Compton spectrum induced in the standard of $\mathrm{H}-3$ scintillation cocktail by an external ${ }^{133} \mathrm{Ba}$ gamma source.

\subsection{Dose assessment}

The committed effective dose for general public was evaluated considering a conservative hypothesis for contamination by drinking water ingestion that would come from an existing hypothetical well.

The dosimetric model adopted [9] considers the radioactive material concentration that would be ingested by drinking the water from this well and a dosimetric factor, as described in equation (2):

$$
E_{(50)}=A \times B \times D C F
$$

Where:

$\boldsymbol{E}_{(50)}=$ committed effective dose $\left(\mathrm{Sv} \cdot \mathrm{year}^{-1}\right)$

$\boldsymbol{A} \quad=$ radionuclide concentration $\left(\mathrm{Bq} \cdot \mathrm{L}^{-1}\right)$

$\boldsymbol{B} \quad=$ rate of annual drinking water consumption $\left(\mathrm{L} \cdot \mathrm{year}^{-1}\right)$.

$\mathbf{D C F}=$ dose conversion factor for the radionuclide ingested $\left(\mathrm{Sv} \cdot \mathrm{Bq}^{-1}\right)$

It was considered an ingestion of approximately 2 liters of water per day [10], coming from that hypothetical well, reaching a total of 800 liters by year. For the radionuclide concentration, it was used the maximum concentration obtained for tritium in four years of analysis in the IPEN Environmental Monitoring Program wells. For the tritium dose conversion factor (DCF) it was adopted the Safety Series 115/1994 [11] value of $1.8 \times 10^{-11} \mathrm{~Sv} \cdot \mathrm{Bq}^{-1}$.

\section{EXPERIMENTAL RESULTS}

\subsection{IPEN Environmental Monitoring Program}

135 groundwater samples bimonthly collected from the 6 wells of the IPEN Environmental Monitoring Program during the period from 2000 to 2003 were analyzed by liquid scintillation for tritium assessment. The location of the wells related with the IPEN facilities is identified in table 1. Figure 2 shows the results of tritium specific activities. The minimum detectable activity of the Packard Tri-Carb 2100 TR spectrometer was $20.6 \mathrm{~Bq} \cdot \mathrm{L}^{-1}$. The null results represent values below the detection limit or a dry well at sampling time. 
Table 1. Relative localization of wells from IPEN Environmental Monitoring Program.

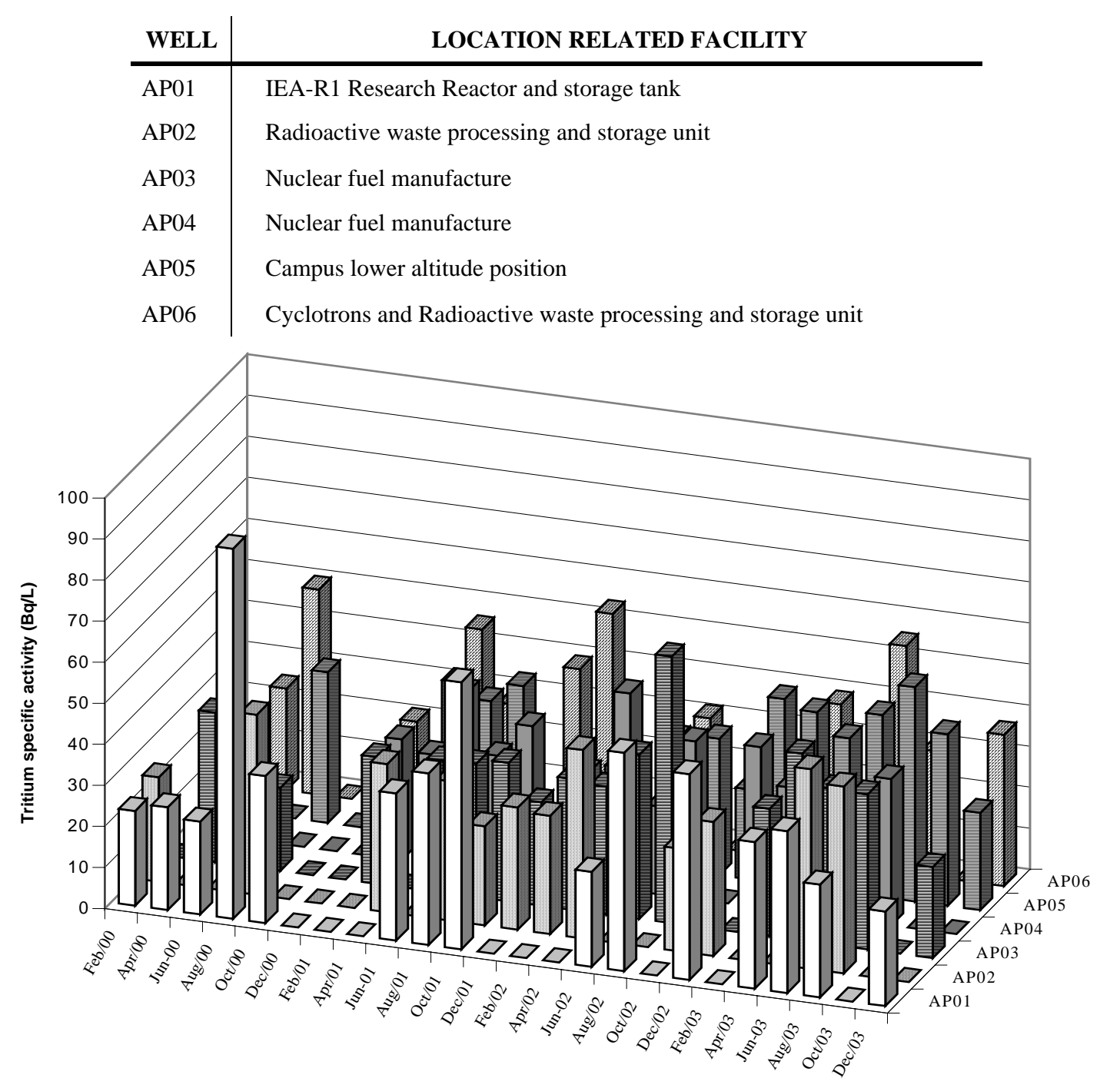

Figure 2. Specific activity of tritium in the wells of IPEN Environmental Monitoring Program from 2000 to 2003.

The committed effective dose for general public, calculated as in equation 2 and considering the groundwater maximum tritium specific activity of $90.1 \mathrm{~Bq} \cdot \mathrm{L}^{-1}$ is $1.3 \mu \mathrm{Sv} \cdot \mathrm{y}^{-1}$.

\subsection{Radioactive liquid effluents}

The tritium specific activity was also determined for four radioactive liquid effluents samples from the IEA-R1 storage tank. Figure 3 shows the results compared to the Brazilian daily limit of discharge [12]. 


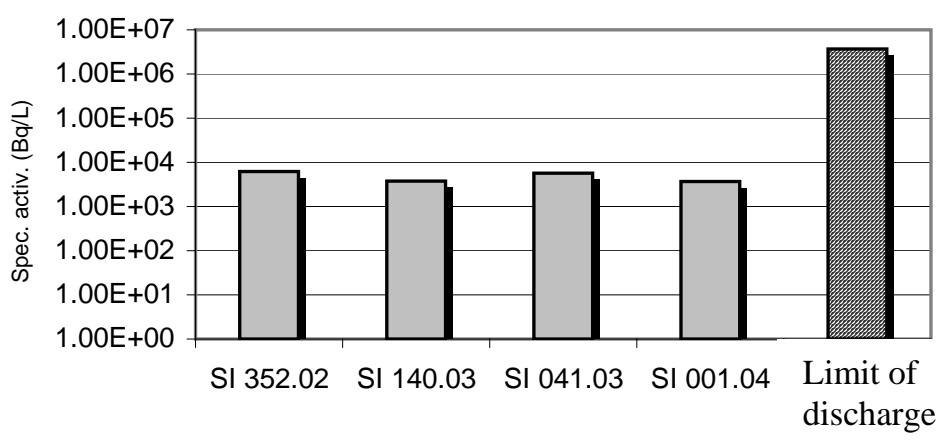

Figure 3. Specific activity of tritium in liquid radioactive effluents from IEA-R1 nuclear research. react.storage tank.

\section{CONCLUSIONS}

\subsection{Tritium in groundwater from the IPEN Environmental Monitoring Program}

The average specific activity of tritium in the groundwater was $21.1 \mathrm{~Bq} \cdot \mathrm{L}^{-1}$. This value is in good agreement with literature values for radioactive facilities with the same characteristics as IPEN ones [13]. Higher tritium concentrations tendency for months of lower or no rain precipitation suggests that there is a relationship between tritium in the air and in the groundwater, since the aquifer in area under IPEN influence receives rain. The largest values of $90.1 \mathrm{~Bq} \cdot \mathrm{L}^{-1}$ are about $10^{2}$ smaller than the EPA limit of $740 \mathrm{~Bq} \cdot \mathrm{L}^{-1}$ for drinking water [14].

Those results, together with the gamma measurements [5] and thermoluminescence dosimeters results [6], show the effectiveness of the radiological control of IPEN.

\subsection{Tritium in the radioactive liquid effluents of the IEA-R1 research reactor}

The results for the radioactive liquid effluents of the IEA-R1 research reactor show a considerable presence of tritium. However, even considering the most conservative hypothesis with no dilution and relating the total activity with the volume to be discarded, the specific activity is by $10^{3}$ times lower than the discharge limits established by the competent Brazilian authority. Those results show that tritium evaluation is essential for the radiological control of IPEN.

\subsection{Dose assessment due to the tritium in groundwater}

The committed effective dose value of $1.3 \mu \mathrm{Sv} \cdot \mathrm{y}^{-1}$ due to the ingestion of tritium water for general public is approximately 1800 times lower than the effective dose value of $2.4 \mathrm{mSv}^{\cdot-1} \mathrm{y}^{-1}$ due to natural

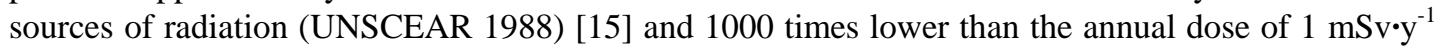
for the general public (ICRP-60) [9]. 


\section{References}

[1] COMISSÃO NACIONAL DE ENERGIA NUCLEAR, Diretrizes Básicas de Radioproteção, Rio de Janeiro. 1988. (CNEN-NE-3.01)

[2] JACOMINO, V. M. F., MÁDUAR, M.F. Avaliação radiossanitária do sistema aquático sob influência do IPEN-CNEN/SP. São Paulo: IPEN, dez. 1989 (IPEN-pub-282).

[3] INTERNATIONAL ATOMIC ENERGY AGENCY. Principles of limiting releases of radioactive effluents into environment. Vienna, 1986 (IAEA-SS-77).

[4] JACOMINO, V. M. F., MÁDUAR, M.F. Monitoração ambiental nas imediações de instalações nucleares. São Paulo: IPEN, fev. 1992 (IPEN-pub-363).

[5] SANDRA R. DAMATTO, M. F. MÁDUAR, M. B. NISTI, M. M. DE ALENCAR, BRIGITTE R. S. PECEQUILO Results from gamma ray spectrometry measurements obtained within the environmental monitoring program at IPEN, ECORAD 2004, to be presented.

[6] BRIGITTE R. S. PECEQUILO, MARCIA P. CAMPOS, MARCOS M. ALENCAR and MARCELO B. NISTI Ipen Environmental Monitoring Programme: Assessment of the Gamma Radiation Levels with Thermoluminescent Dosimeters, First International Meeting on Applied Physics (APHYS-2003) Badajoz, Spain, October, 13 - 18, 2003.

[7] CASTELLANO, S. D.; DICK, R. P. Measurement of Tritium Activity in Soils, Health Physics, Vol. 65, No. 5, pp. 539 - 540, 1993.

[8] WOOD, M. J.; MCELROY, R.G.C.; SURETTE, R.; BROWN, R. M. Tritium Sampling and Measurement, Health Physics, Vol. 65, No. 6, pp. 610 - 627, 1993.

[9] ICRP-60. INTERNATIONAL COMMISSION ON RADIOLOGICAL PROTECTION. 1990 Recommendations of the international commission on radiological protection. Pergamon Press. Oxford, 1991. (ICRP-60).

[10] ICRP-23. INTERNATIONAL COMMISSION ON RADIOLOGICAL PROTECTION. Report of task group on reference man. Pergamon Press. Oxford, 1975. (ICRP-23).

[11] SS-115 SAFETY SERIES 115. International Basic Safety Standards for Protection Against Ionizing Radiation and for the Safety of Radiation Sources. Viena, 1994.

[12] COMISSÃO NACIONAL DE ENERGIA NUCLEAR, Gerência de Rejeitos Radioativos em Instalações Radiativas, Rio de Janeiro. 1985. (CNEN-NE-6.05).

[13] MORAES, M. A. P. V.; SARTORATTO, M.; SARTORATTO, B. E. L.; OLIVEIRA, C. B.; MENDES, V. A.; Tritium concentration analysis in environmental water samples of Centro nuclear ARAMAR (CTMSP - Brazil), Radiation Measurement, Vol. 35, pp. 333 - 337, 2002.

[14] EPA, - U.S. ENVIRONMENTAL PROTECTION AGENCY - Tentative Reference Method for tritium concentrations analysis, 1975, in MARCO ANTONIO P. V. MORAES, MARCELO SARTORATTO, BÁRBARA E. L. SARTORATTO, CAROLINA B. OLIVEIRA, VIVIAN A. MENDES, Tritium concentration analysis in environmental water samples of Centro nuclear ARAMAR (CTMSP - Brazil), Radiation Measurement, Vol. 35, pp. 333 - 337, 2002.

[15] UNSCEAR. United Scientific Committee on the Effects of Atomic Radiation. Sources, effects and risks of ionizing radiation. New York, U.N., 2000. 